\title{
Cultural translation: An introduction to the problem, and Responses
}

Sherry Simon, Département d’études françaises, Concordia University, Montréal, Canada

The full version of this article appears in Translation Studies,2:2, 2009, 208-212. Available at http://dx.doi.org/10.1080/14781700902937730.

The circulation of concepts across disciplines and geographies is full of lessons. And really good analyses of the travels of ideas-- like François Cusset's French Theory, an account of the way that French thought was taken up in the U.S. during the 1970s and 1980s-- are valuable for what they tell us of the meeting between people, institutions and concepts. The trajectory of translation studies, when its arc one day becomes clear, will also be a revealing chapter in the history of ideas. But for the moment, its travels still seem to be full of surprising twists. And one of these is the increasing importance of “cultural translation” as a platform of analysis, especially in the European context. The rich collection of articles found on the eipcp website is striking evidence of the way cultural translation is being mobilized in the critique of nationalism, social exclusions, and narrow definitions of multiculturalism. The term serves as a rallying point for a broadly activist academic agenda -- in particular in relation to the ways that citizenship is being tested and borders instrumentalized.

A similar emphasis on translation—accompanied by a new vocabulary of academic militancyhas taken place in the United States, largely through Comparative Literature. Placing travel, geography and power at the centre of analysis, the "new" Comparative Literature looks both for new definitions of world literature (Apter, Damrosch), for a renewed emphasis on second languages and bilingual esthetics (Pratt, Spivak) and for a redefinition of the United States as a vigorously plurilingual space (Sommer, Dimock). But, perhaps more significantly, translation 
has emerged within the sightlines of disciplines which historically have paid scant attention to it. The broadest statement of this change is the declaration by Dilip Gaonkar and Elizabeth Povinelli in their introduction to an important issue of the cultural studies journal Public Culture entitled “Technologies of Public Forms: Circulation, Transfiguration, Recognition” :"It is no longer viable to look at circulation as a singular or empty space in which things move..,” they say. And qualify this statement with a further development: "A form can be said to move intelligibly from one cultural space to another only in a state of translation.” (p.. 392) Focus shifts then to the effects of mediation, to the ways practices of communication shape the knowledge that we receive, to the ways in which it is developed, organized, and passed on. The emphasis on circulation, transmission, passing on, shapes a strong conceptual context for the study of "entangled objects" (Pinney, 1998) -that is, objects whose meanings are inflected by the networks through which they circulate. Across the humanities, then, there is a recognition that transmissive means are also transfigurative (Povinelli and Gaonkar) Translation (and not transfer) names the complexity of these processes, englobing geography and textuality. This recognition has led to ambitious research projects as well as new transdisciplinary masters and doctoral programs who use the broad "cultural translation" as a centre of inquiry into meaning creation which focuses on the political geographies of displacement.

As it migrates across disciplines, translation is also applied to changing situations. With the intensification of migration, diasporal communities and cultural hybridity, translation operates increasingly across small spaces, "at home”. Multilingual contexts and multilingual forms of communication call for new ways of thinking about transfer, and the ways in which language relations are inflected by the proximity of differences. Michael Cronin's notion of the new cosmopolitanism, but also the idea of "endotropic travel"—of movement across small, "internal" 
spaces-applies to the complexities of translation across the shared spaces of today's cities, for instance. How then do multilingual situations, where communities share a common geographical space — or compete for it—inflect the process of cultural creation? The spaces of cities offer a new terrain for translation studies, in particular cities which have a long history of linguistic cohabitation, where more than one community lays claim to the territory.

The fact, however, that Buden and Nowotny refer to the "problem" of cultural translation in the title of their article, points to areas of concern. This is most specifically a malaise of definition. What makes translation “cultural”? Buden and Nowotny define their version of cultural translation as the offshoot of a powerful counter-tradition in European thought, the line issuing from Benjamin and running through Derrida, Jakobson and Bakhtin and which refuses the regulatory functions of translation (as reproduction, as transfer), by giving translation a foundational status. This is in contrast to the more normative line of thinking which has historically served a nation-building program, propping up normative conceptions of language, nation, property and authorship. They find expression of this normative tradition in Humboldt's idea of "translation as cultivation”. They could also have found it in Mme de Stael's equally bold appeal to translation - as a welcoming of the foreign which nevertheless serves to reinforce the distinctive character of the national spirit. From the first definition of modern translation by the Italian Humanists in the early years of the Renaissance, there has been a link of solidarity between translation and normative institutions and so translation has functioned as a regulatory mechanism, reproducing the "the ideological configuration of social relations”.

Buden and Nowotny look to the counter-tradition, beginning with Benjamin, to construct an alternative view. When meaning creation is a translative operation (Jakobson), when translation 
is a "mother tongue" (Ivekovic), then it can no longer operate as a process reproducing and policing the borders of authorship, language, nation. The categories themselves are adulterated. Jakobson makes the link even more firm when he places translation at the heart of meaningmaking processes, just as Bakhtin placed polyphony at the heart of the narrative. Naoki Sakai's definition of translation as "a social relation" rather than a transfer between two predetermined units is a continuation of this mode of thinking. Rather than a mode of communication (transfer) he foregrounds social relations and modes of address, homolingual and heterlingual.

It would be fair to say that translation studies has long been aware of these opposing regimes and the influence of the "countertradition" has been crucial to many varieties of Translation Studies, from the feminist theorists of the 1980s and 1990s to postcolonial translation studies. In these views, "culture" is not a protective envelope but an object of suspicion. "This destabilizes the view of translation as a 'bridge between cultures' or makes it obsolete, since - if we draw on postcolonial theories of culture - translational transfer takes place between cultures that are already contaminated in themselves. (M. Wolf, 2008). And so it sometimes seems as if the default kind of translation studies (the kind that is not cultural translation) is a kind of straw dog. There cannot be a clear cut distinction between cultural translation and the ordinary kind, because, as Buden and Nowotny show, even the linguistic categories used to define translation are more than linguistic. And so translation studies—in whatever form it takes—engages with categories and norms, either to confirm the normalizing tendencies of translation or to draw attention to the ways in which translation can disturb existing regimes.

But there is another layer to this debate and it has been discussed by Harish Trivedi. Trivedi rightly points out that cultural translation has become a way for cultural studies theorists to 
appropriate "translation"-without learning the languages. Applied to colonial practices of knowledge-creation, to human migrancy, to bilingual or diasporic situations of writing, translation becomes an indicator of the global reach of monolingual Anglo-American cultural studies. "And then those of us who are still bilingual, and who are still untranslated from our own native ground to an alien shore, will nevertheless have been translated against our will and against our grain.” (Trivedi) For Trivedi, “cultural translation” is the threat of monolingualism and planetary English, it is the expression of the power of diasporic intellectuals over the ones who have stayed home.

But is the solution to turn to a kind of academic protectionism, to the reservation of exclusive titles to qualified practitioners? It makes more sense to enlarge the field, as Maria Tymoczsko argues so persuasively in her last book—and as many other translation studies scholars have been doing over the last years. The list of remarkable scholarly books that use translation as their conceptual pivot increases each year. Among many examples—Faithful Renderings. JewishChristian Difference and the Politics of Translation by Naomi Seidman (University of Chicago Press, 2006) and Provincializing Europe by Dipesh Chakrabarty (2000). Let me just briefly discuss this last book as an example of a rich exploration using translation to nourish historical investigation. Provincializing Europe has already become a classic, not least because of its compelling title. Chakrabarty argues the postcolonial case: postcolonial societies should not be forever required to languish in the "waiting rooms of history" as the always belated recipients of European ideas. But in response to the historical dissymetries of intellectual authority, to the unequal dialogue between concepts born in the European context and the tools of postcolonial recovery, his position is a remarkably tempered one. In a now well-known formulation, he argues: AEuropean thought is both indispensable and inadequate in helping us to think through 
the various life practices that constitute the political and the historical in India.@. (p.6) and AThe very critique of colonialism is unthinkable except as a legacy, partially, of how Enlightenment Europe was appropriated in the subcontinent. P.4) The alternative concepts that might have emerged out of the Sanskrit, Persian or Arabic traditions are not available, the intellectual linkages broken by British colonialism. And so, this legacy is only now a matter of historical research for modern social science, while "past European thinkers and their categories are never quite dead for us in the same way@. Following Homi Bhabha=s theoretical lead, but adding needed flesh where Bhabha provides only a skeleton, Chakrabarty makes translation an important lens through which to view the traffic in ideas. This applies not only to the concepts studied but to the way that historical writing is itself undertaken. Which concepts are to serve as grounds for thought, and how are these to be translated into historical method and debate? 
AThe problem of capitalist modernity cannot any longer be seen simply as a sociological problem of historical transition..but as a problem of translation, as well. There was a timeBbefore scholarship itself became globalizedB when the process of translating diverse forms, practices, and understandings of life into universalist political-theoretical categories of deeply European origin seemed to most social scientists an unproblematic proposition. That which was considered an analytical category (such as capital) was understood to have transcended the fragment of European history in which it may have originated” (p. 18)

But it is now understood, says Chakrabarty, that "rough" translation is inadequate, and that "critical and unrelenting attention" must be paid to the process of translation. Between the poles of incommensurability (resulting from crude domination) and successful mediation, Chakrabarty points to the "partly opaque relationship we call ‘difference’”. Following Benjamin and Bhabha, he calls for "narratives and analyses that produce this translucenceBand not transparencyBin the relation between non-Western histories and European thought and its analytical categories”.. (p.18)

One example of such a narrative is his discussion of the poet and thinker Rabindranath Tagore in relation to the idea of the nation. Juxtaposing Tagore's 'viewing' of the nation and Benedict Anderson’s successful formula "imagined community", Chakrabarty wonders how the very category of the imagination has made its way across conceptual and linguistic lines--questioning whether one can in fact stand as the equivalent of the other. Rather than taking the category of "nation" as the focus of discussion, he shifts instead to the idea of "imagination". AWas >piercing the veil of the 
real=Bthe phrase Tagore used to describe the mode of viewing in which India appeared as already lovable-- was this mode of viewing the same as what is conveyed by >imagining= in Benedict Anderson=s book on nationalism?

"I do not intend to reduce Tagore=s point about $>$ seeing beyond the real= to practices that preceded British rule in Indian and thus present Indian nationalism as a site of an unbridgeable difference between the West and the East. Tagore (and nationalism in general) obviously derived much from European romanticism. His idea of the transcendental was unmistakably idealist. My point is that the moment of vision that effected a >cessation of the historical world= included plural and heterogeneous ways of seeing that raise some questions about the analytical reach of the European category >imagination=. A (Chakrabarty, p)

Chakrabarty is careful not to opposite east and west, Europe and India. Tagore is very much a product of European romanticism, yet Chakrabarty is suggesting that the way Tagore "imagines" the nation in his poetry is both the same and different from the received meaning of this word. And so translation gives him an angle of approach which is revealing of conceptual dissymetries.

As a Bengali intellectual, schooled in the lessons of the Bengali Renaissanceitself a remarkable translational event—Chakrabarty brings a singular perspective to the discipline of history. As much as the contributors to the eipcp website, his is an activist stance, which challenges the borders of language and nation. Translation studies can only benefit from such interventions and from generalized attention to its topic. 
Cusset, François, French Theory.How Foucault, Derrida, Deleuze, \& Co. Transformed the Intellectual Life of the United State. Trans. Jeff Fort. University of Minnesota Press, 2008.

Chakrabarty, Dipesh, Provincializing Europe: Postcolonial Thought and Historical Difference . Princeton, Princeton University Press, 2000.

Cronin, Michael, Translation and Identity. London, Routledge, 2006.

Damrosch, David. What is World Literature? Translation/Transnation. Princeton and Oxford: Princeton University Press, 2003.

Dimock, Wai Chee, "Planetary Time and Global Translation: "Context" in Literary Studies”, Common Knowledge 9.3 (2003) 488-507)

Gaonkar, Dilip Parameshwar and Elizabeth A. Povinelli, “Technologies of Public Forms: Circulation, Transfiguration, Recognition”. Public Culture 15 (3): 385-397. (2003) Pinney, Christopher, Camera Indica: The Social Life of Indian Photographs. University of Chicago Press, Co-published with Reaktion Books. 1998.

Pratt, Mary Louise. "Building a New Public Idea about Language." Profession 2003, MLA (2003): 110-19.

Seidman, Naomi, Faithful Renderings. Jewish-Christian Difference and the Politics of Translation (University of Chicago Press, 2006)

Spivak, Gayatri, “Translation as Culture”, In Translation. Reflections, Refractions, Transformations, Ed. Paul St-Pierre, Prafulla C. Kar, Delhi, Pencraft International 2005, pp. 238-50. 
Trivedi, Harish, “Translating Culture vs. Cultural Translation”, In Translation.

Reflections, Refractions, Transformations. Ed. Paul St-Pierre, Prafulla C. Kar, Delhi, Pencraft International, 2005.pp. 251-260.

Sommer, Doris. Bilingual Aesthetics. A Sentimental Education. Durham and London: Duke University Press, 2004.

Tymoczsko, Maria, Enlarging Translation, Empowering Translators. Manchester, St.Jerome Press, 2007.

Wolf, Michaela,“Translation-Transculturation. Measuring the perspectives of transcultural political action” eipcp web site, “Traversal”, 06.2008. 